\title{
Altered gene expression in asymptomatic SHIV-infected rhesus macaques (Macacca mulatta) Erica E Carroll ${ }^{\dagger}$, Rasha Hammamieh ${ }^{\dagger}$, Nabarun Chakraborty, Aaron T Phillips, Stacy-Ann M Miller and Marti Jett*
}

Address: Division of Pathology, Walter Reed Army Institute of Research, Silver Spring, Maryland, USA

Email: Erica E Carroll - Erica.Carroll@afip.osd.mil; Rasha Hammamieh - rasha.hammamieh@na.amedd.army.mil; Nabarun Chakraborty - nabarun.chakraborty@na.amedd.army.mil; Aaron T Phillips - aaron.phillips@na.amedd.army.mil; StacyAnn M Miller - stacy-ann.miller@na.amedd.army.mil; Marti Jett* - marti.jett@na.amedd.army.mil

* Corresponding author †Equal contributors

Published: 06 September 2006

Virology Journal 2006, 3:74 doi:10.1 I86/1743-422X-3-74

This article is available from: http://www.virologyj.com/content/3/1/74

(C) 2006 Carroll et al; licensee BioMed Central Ltd.

This is an Open Access article distributed under the terms of the Creative Commons Attribution License (http://creativecommons.org/licenses/by/2.0), which permits unrestricted use, distribution, and reproduction in any medium, provided the original work is properly cited.
Received: 06 July 2006

Accepted: 06 September 2006

\begin{abstract}
Simian-Human immunodeficiency virus is a chimeric virus which, in rhesus macaques (Macacca mulatta) closely imitates immunodeficiency virus infection in human (HIV). A relatively new way to study pathogenesis of viral infection is to study alterations in host gene expression induced by the virus. SHIV infection with certain strains does not result in clinical signs. We hypothesized that alterations in gene expression relating to the immune system would be present in SHIV-infected animals despite the lack of clinical signs. Splenic tissue from four adult male Indian-origin Rhesus monkeys serologically positive for non-pathogenic SHIV 89.6 was processed by cDNA microarray analysis. Results were compared with the corresponding outcome using splenic tissues from four unexposed adult male Rhesus monkeys. Subsequent gene analysis confirmed statistically significant variations between control and infected samples. Interestingly, SHIV-infected monkeys exhibited altered expression in genes related to apoptosis, signal transduction, $\mathrm{T}$ and $\mathrm{B}$ lymphocyte activation and importantly, to immune regulation. Although infected animals appeared asymptomatic, our study demonstrated that SHIV-infected monkeys cannot reliably be used in studies of other infectious agents as their baseline gene expression differs from that of normal Rhesus monkeys. The gene expression differences in SHIV-infected animals relative to uninfected animals offer additional clues to the pathogenesis of altered immune function in response to secondary infection.
\end{abstract}

\section{Background}

Simian immunodeficiency virus (SIV) infection of rhesus macaques exhibits many similarities to human immunodeficiency viral (HIV) infection of humans. Most pathogenesis and vaccine studies for HIV-1 have been undertaken in either SIV-macaque or a chimeric simianhuman immunodeficiency (SHIV)-macaque model [1]. SHIV strains have the viral envelope of HIV but the gag/ pol genes of SIV. Pathogenesis is similar with respect to macrophage and T lymphocyte cell tropism, histopathologic changes, CD4-cell depletion and clinical signs of auto-immune deficiency syndrome (AIDS) in virulent strains. HIV and SIV additionally cause cognitive and motor impairments in infected patients and monkeys, respectively [2]. Host factors may play a role in degree of pathogenesis between varying SHIV constructs, as one study reported observing similar viral loads in rhesus 
monkeys infected with pathogenic and non-pathogenic SHIV constructs [1].

Gene expression studies have grown increasingly popular as a tool to mine large amounts of data from treated and control populations. Such data can be used to examine host factors involved in SHIV, and thereby HIV, pathogenesis. To our knowledge, microarray data from SHIVinfected Rhesus macaques have not yet been examined for genes affecting immune response and inflammation. Gene expression data have the potential to greatly expand the understanding of SHIV-host interaction beyond the limited number of cell types or cytokines generally examined.

In animals free of clinical signs of SHIV, altered baseline gene expression data may give clues to the pathogenesis of altered immune response to secondary infections. Studies involving HIV-infected humans demonstrated suppression of IL-2 in response to select antigens and increase in TNF- $\alpha$ even prior to the onset of CD4+ T-cell depletion $[3,4]$. Gene expression data collected in this study from SHIV 89.6-infected monkeys demonstrate that these animals are not genetically 'normal' and cannot ethically be used for studies involving other infectious agents, if at all, without an explicit caveat listing their SHIV status. Comparison of gene expression patterns collected from SHIVinfected and uninfected animals to that of the matched animals exposed to select bacterial and viral agents would provide a more complete understanding of SHIV effect on immune response to particular infectious agents. Extrapolation to the HIV-patient response to secondary agents may then be attempted. Gene expression data may also provide clues to pathogenesis of cognitive and related ailments arising with HIV infection.

\section{Results}

\section{Clinical history}

A brief description of treated and control animals is given in Table 1. All monkeys were male; while two of them (one SHIV-positive, one SHIV-negative) were Herpes Bpositive.

Table 2 summarizes abnormalities in clinical chemistries including complete blood counts of the SHIV-infected animals. Abnormalities were minimal. Attending veterinary clinicians considered these animals asymptomatic with respect to SHIV infection.

\section{Micro-array analysis of SHIV-infected versus uninfected}

Using the 38 most varying genes between SHIV-infected and SHIV-uninfected animals, we performed Principle Component Analysis, a non-hierarchal clustering tool, to revalidate the $t$-test result. Figure 2 demonstrates that the SHIV positive and negative groups were clustered together, keeping a significant distance between them along the first principal component (X-axis), which shared the highest fraction of group variation. The pattern of clustering also suggested that the gene expression variability was independent of the animals' Herpes B status.

Gene ontology study, using GeneCite [6], associated the members of the differentially expressed genes to a range of important biological and pathological functions including immune defense, cell death or apoptosis, cell growth, signal transduction and others. Table 4 represents the functional classification of some of the genes of interest.

\section{Confirmation of gene expression changes by Real-Time PCR analysis}

Ten genes were selected for real-time polymerase chain reaction (PCR). They are RNA binding motif protein 9 ( $\underline{\text { AA451903 }})$, collagen, type XV, alpha 1 (吕455157), collagen, type VII, alpha 1(AA598507), interleukin 2 receptor, alpha (AA903183), Chloride channel, calcium activated, family member 2 (AI675394), mitogen-activated protein kinase kinase (H85962), adenosine A2a receptor $(\underline{\mathrm{N} 57553})$, programmed cell death 4 (N71003), postmeiotic segregation increased 2-like (AA922998), Bcl-2 inhibitor of transcription (AI339248) and Anillin (R16712). Figure 3 illustrates that the real-time PCR expression profiles for the selected genes are well correlated with the corresponding microarray results.

\section{Discussion}

Simian immunodeficiency virus (SIV), previously referred to as simian T-cell lymphotropic virus type III (STLV-III), induces an AIDS-like disease in its natural host, rhesus macaques. HIV and SIV, members of the lentivirus subfamily of retroviruses, not only resemble each other by their antigenicity, but also bear remarkable similarity in their biological properties, such as cytopathic effect and tropism for CD4-bearing cells. These criteria render the chimeric SHIV the best animal model currently available for HIV study.

In this study, we examined gene expression in SHIVinfected male rhesus macaques of Indian origin using a genomic perspective and compared the results to uninfected age, gender and Herpes B-status-matched controls. Although infected animals were without clinical signs related to SHIV infection, a significant number of genes exhibited significantly altered expression concurrent with SIV

infection.

Ontological research revealed that several genes, namely

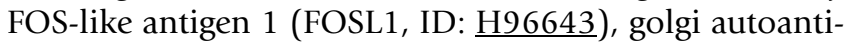
gen (GOLGA2, ID: AA424786), major histocompatibility complex (MHC), class II, DR beta 1 (HLA-DRB1, ID: $\underline{\mathrm{AA} 664195}$ ) and leukocyte immunoglobulin-like receptor 
Table I: An overview of the Rhesus macaques used in SHIV gene expression study

\begin{tabular}{llllll}
\hline Animal ID & Gender & Age $(\mathbf{y r s})$ & Geographic origin & Herpes B Status & SHIV 89.6 status \\
\hline JGH & Male & 7 & Indian & positive & positive \\
PHB & Male & 7 & Indian & negative & positive \\
TTH & Male & 7 & Indian & negative & positive \\
FFG & Male & 9 & Indian & negative & positive \\
331 & Male & adult & Indian & negative & negative \\
332 & Male & adult & Indian & negative & negative \\
CJ2T & Male & 4 & Indian & negative & negative \\
EC49 & Male & adult & Indian & positive & negative \\
DB87 & Male & 12.2 & Indian & & \\
\hline
\end{tabular}

(LILRB3, ID: AI815229) are associated with human immune defense. LILRB3 is a leukocyte inhibitory receptor which, upon binding to MHC Class I molecules, transmits inhibitory signals to the nucleus. HLA-DRB1, down regulated by SIV infection, is a cell-surface-associated immunoregulatory protein. Interestingly, this human leukocyte antigen (HLA)-associated gene has been correlated with non-responsiveness to recombinant hepatitis $B$ virus (HBV) vaccine but does not alter susceptibility to viral persistence [6]. Another MHC protein binding unit, T cell receptor alpha locus (TRAC, ID: AA427491) is ontologically related to signal transduction.

Gene ontology investigation classified a significant subset of the genome of interest as a regulator of cell growth and apoptosis. SIV infection results in down-regulation of apoptosis inhibitor 5 (API5, ID: AI972925) and up-regulation of pro-apoptotic protein phorbol-12-myristate-13acetate-induced protein 1 (NOXA, ID: $\underline{\text { AA458838) }}$ [8]. These alterations in gene expression might instigate opportunistic infections by inducing apoptosis among T- helper lymphocytes. Likewise, SIV infection alters several metabolism and cell growth regulating factors. For example, SIV-infected genome contains upregulated aldehyde dehydrogenase 5 family member A1 (ALDH5A1, ID: $\underline{\mathrm{H} 06676})$; and concurrent down regulated succinate dehydrogenase complex, subunit D (SDHD, ID: AA035384) and nephropathic cystinosis (CTNS, ID: W94331). Reports suggest that overexpressed ALDH5A1 changes the concentration of gamma-aminobutyric acid (GABA) and glutamate, commencing henceforth excitotoxic damage, a well-established clinical marker of HIV activity [9]. Underexpressed SDHD and CTNS are associated with immunodeficiency through curbed monocyte and CD4+ $\mathrm{T}$ cell -induced immunoregulation [10], respectively.

Several entries of the present genome are functionally related to cellular and molecular transportation and binding. Interestingly, five actin-binding genes appeared in the list; namely: anillin (ANLN, ID: R16712), destrin (DSTN, ID: AA424824), utrophin (UTRN, ID: AA676840), cyclindependent kinase 2-interacting protein (CINP, ID:

Table 2: Clinical pathology of SHIV-positive rhesus macaques

\begin{tabular}{|c|c|}
\hline Animal ID & Abnormal findings in complete blood count and serum chemistry analysis. \\
\hline FFG & $\begin{array}{l}\text { Sodium I } 44 \mathrm{mg} / \mathrm{dl} \text { (reference range I47-I58) } \\
\text { Chloride } 108 \mathrm{mg} / \mathrm{dl} \text { (range I I0-120) } \\
\text { Lymphocytes } 65.4 \% \text { (reference range 14-64\%) }\end{array}$ \\
\hline PHB & $\begin{array}{c}\text { Sodium } 146 \mathrm{mg} / \mathrm{dl} \text { (range I47-158) } \\
\text { Carbon dioxide } 29 \mathrm{mmol} / \mathrm{L} \text { (range 19-29) } \\
\text { Total protein } 6.4 \mathrm{~g} / \mathrm{dl}(\text { range 6.7-8.0) } \\
\text { ALT II } 3 \text { U/L (range 20-9l) } \\
\text { LDH } 538 \mathrm{U} / \mathrm{L} \text { (range 638-30I2) }\end{array}$ \\
\hline TTH & $\begin{array}{c}\text { Sodium } 145 \mathrm{mg} / \mathrm{dl}(\text { range I47-158) } \\
\text { Chloride } 110 \mathrm{mg} / \mathrm{dl}(\text { range I I0-120) } \\
\text { AST } 29 \mathrm{U} / \mathrm{L} \text { (range 29-64) }\end{array}$ \\
\hline JGH (Herpes B+) & $\begin{array}{c}\text { Sodium } 147 \mathrm{mg} / \mathrm{dl} \text { (range I47-158) } \\
\text { Chloride } 109 \mathrm{mg} / \mathrm{dl} \text { (range I I0-120) } \\
\text { Carbon dioxide } 30 \mathrm{mmol} / \mathrm{L} \text { (range 19-29) } \\
\text { Triglycerides } 18 \mathrm{mg} / \mathrm{dl}(\text { range 35-137) } \\
\text { Total protein } 6.6 \mathrm{~g} / \mathrm{dl} \text { (range 6.7-8.0) } \\
\text { AST } 26 \mathrm{U} / \mathrm{L} \text { (range 29-64) }\end{array}$ \\
\hline
\end{tabular}



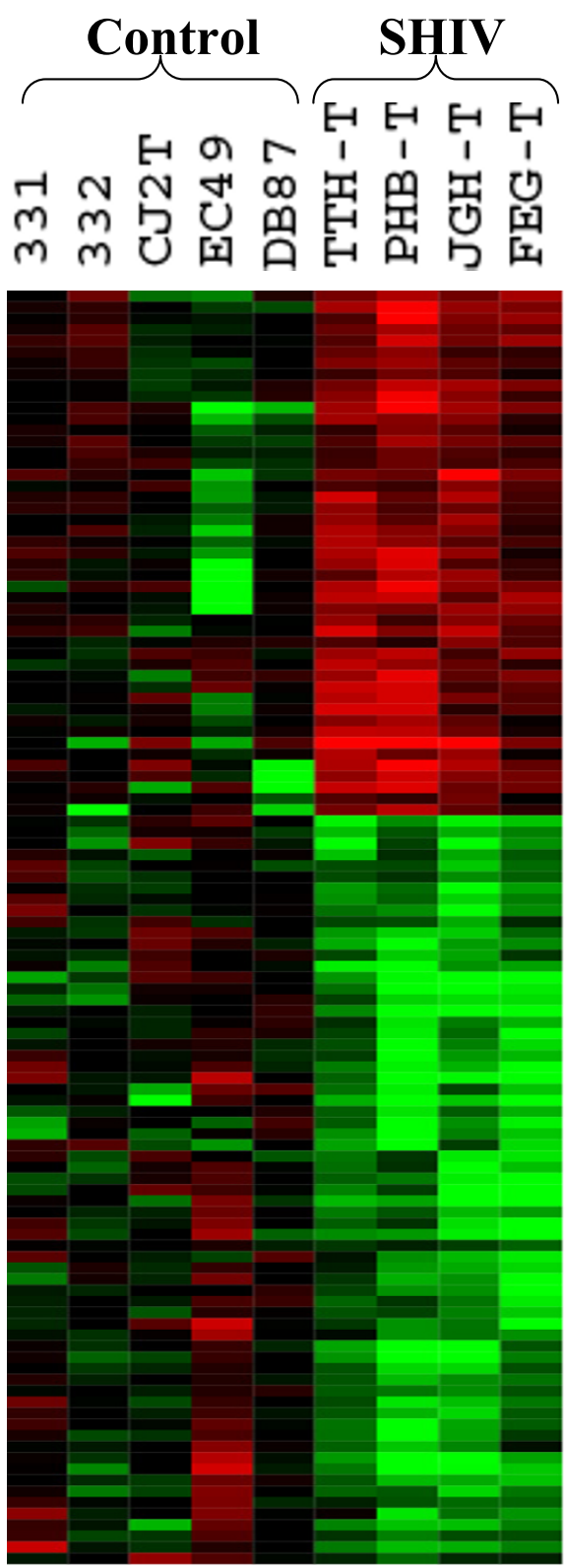

\section{Figure I}

Hieratically clustered Tree-view of genes differentially expressed between the SHIV positive and negative animals.

$\underline{\text { AI364103) }}$ and IQ motif containing GTPase activating protein 2 (IQGAP2, ID: W32272). Actin, the ubiquitously present cellular protein, has been reported to guide the direct cell-to-cell HIV-1 propagation by making of a stable adhesive junction at the target-effector cell interface [11]. Table 4 displays the down regulation of another molecular binding protein, $15 \mathrm{kDa}$ selenoprotein (SEP15, ID: AA521350). Reduced level of selenoprotein in cells is a known marker of in vitro infection of SHIV [12]. Our data also supports the fact that immunodeficiency is correlated with altered calcium ion binding (UTRN, ID: AA676840;

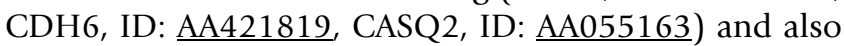
is influenced by calcium- activated chloride channels (CLCA2, ID: AI675394) of host cells. Those are well established pathoregulating markers of activ HIV-1 negative factor (Nef) [13-15].

In summary, in this small sample of SHIV-infected Rhesus macaques, expression was consistently altered in specific groups of genes which regulate a broad range of biochemical functions. A few important members of the genome of interest are discussed here. The present study, along with correlating some genes with SHIV and HIV model, identifies several novel genes as potential therapeutic markers for immune deficiency studies. Furthermore, results of this study suggest that SHIV infection of rhesus macaques may influence immune response to a second agent, even if baseline levels of clinical measurements appear normal. This study substantiates and validates the concern that an infected (i.e., antibody-producing) but asymptomatic animal should not be used in any other study involving infectious agents unless the pattern of gene expression to that agent is compared to normal animals' pattern, one agent at a time.

Note: microarray data have been submitted to the Gene Expression Omnibus (GEO) and can be searched using the Platform ID: GPL3395.

\section{Materials and methods Animals and virus}

Four adult (7-8 years old) male Rhesus macaques (one Herpes B-positive and three Herpes B-negative) that were previously exposed to SHIV 89.6 strain (Animal identifications: FFG, JGH, PHB and TTH) were euthanized due to being declared 'excess' and no longer usable due to their serologically positive SHIV status. Splenic tissue was collected from each animal upon euthanasia and immersed in RNA Later ${ }^{\circledast}$ for 30-60 minutes before freezing at -80C.

SHIV 89.6, like all SHIV strains, has the env gene from the HIV-1 strain. All four animals had been challenged with $1.0 \mathrm{ml}$ intravenous SHIV 89.6, a non-pathogenic strain, and became seropositive. Previous studies by the same researchers showed that seropositive animals were PCR positive as well (WRAIR Protocol TO03-98). All animals remained free of clinical signs. Complete blood counts and serum chemistry profiles were performed on the SHIV-positive animals and were within or very close to normal limits. The negative control animals were Indianorigin adult male Herpes B-negative Rhesus macaques. Splenic tissues were kindly provided by Scripps Institute, the National Institute of Health, and the Oregon National Primate Research Center. Tissue from a SHIV-negative animal (DB-87, provided by the Tulane National Regional 


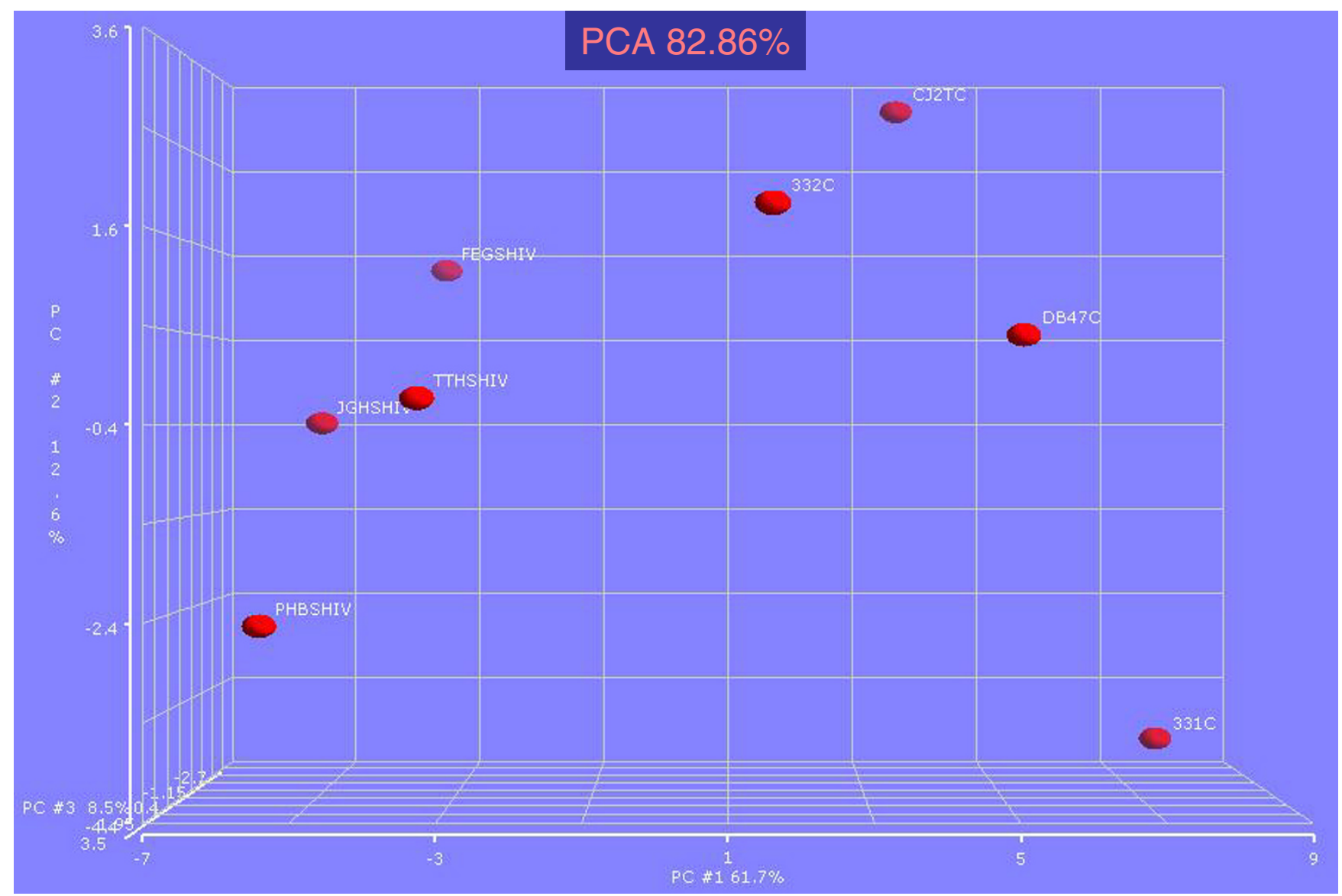

\section{Figure 2}

Principal component analysis was performed over the SHIV infected and non-infected population. Though the animals were clinically reported asymptomatic, the SHIV treated and control samples cluster far from each other along PCAI axis. The result also suggests that the Herpes B status does not affect the outcome. Here PCAI has 6I.7\% population, while PCA2 and PCA3 shares $12.6 \%$ and $8.56 \%$ of the population respectively.

Primate Research Center) was Herpes B-positive to control for the Herpes B-positive status of one SHIV-infected animal Table 1 represents an overview of the Rhesus macaques used in this study. Table 2 shows the clinical results of the SHIV-positive rhesus macaques

\section{RNA isolation}

Splenic tissue samples stored in RNALater ${ }^{\circledast}$ (Ambion, TX) at $-80 \mathrm{C}$ were thawed in $1.5 \mathrm{~mL}$ tubes on ice. Tissue was submerged in Trizol ${ }^{\text {тм }}$ (Invitrogen, CA) solution and RNA isolation was carried out paccording to the Trizol ${ }^{\text {тм }}$ Reagent manufacturer's recommended instructions. RNA was ethanol-precipitated, air-dried and re-suspended in $20 \mathrm{ul} /$ sample of nuclease-free water. RNA quantity was measured via spectrophotometry followed by analysis with a Bioanalyzer 2100 (Agilent Technologies, CA)

\section{Custom made cDNA microarray SlidePreparation and hybridization}

The gene library for the present project was commercially obtained from Research Genetics (Invitrogen, CA), containing 7489 genes, including 7019 known genes, 249 unknown genes and 110 expressed sequence tagged genes (ESTs). Superamine coated Telechem slides (Telechem Inc., OR) were used for printing the cDNA clones using 12 $\times 4$ pin format, on a Virtek chip writer professional microarrayer in KemTek, Inc, MD. The printed slides underwent UV cross-linking, followed by post-processed by succinic anhydride treatment. The Micromax ${ }^{\mathrm{TM}}$ Tyramide Signal Amplification (TSA) ${ }^{\mathrm{TM}}$ Labeling and Detection Kit (PerkinElmer, Inc., MA) was used as directed by the manufacturer to determine relative gene expression of the collected samples. Custom-made reference RNA was prepared by 
Table 3: The sequences of the primers used in the present project

\begin{tabular}{|c|c|c|c|c|}
\hline Name & Gene Bank ID & Description & Sequence & Product Size \\
\hline \multirow[t]{2}{*}{ ANLN } & $\underline{\mathrm{R}} 16712$ & Anilin & 5'-TCC AAG TCC TGT GTC TCC TC-3' & \\
\hline & & & 5'-TCT TGA GTT CAG CCC TCT CC-3' & 109 bp \\
\hline \multirow{2}{*}{ Bit l } & Al339248 & CGI-I47 protein & 5'-TGG CTG TTG GAG TTG CTT G-3' & \\
\hline & & & 5'-TGT GTG TCT TGC TCG TCT TG-3' & $93 \mathrm{bp}$ \\
\hline \multirow[t]{4}{*}{ CLCA2 } & $\mathrm{Al} 675394$ & chloride channel. calcium activated, fam & 5'-CAA CCA AGA AGC ACC AA CC-3' & \\
\hline & & & 5'-CAT CCA GCA CTA AAC AGA CCA C-3' & 179 bp \\
\hline & AA922998 & postmeiotic segregation increased 2-like & 5'-GTT TCA GGC AAT GGA TGT GG-3' & \\
\hline & & & 5'-CAT GGC AGG TAG AAA TGG TG-3' & 178 bp \\
\hline \multirow[t]{2}{*}{ COLI5A } & $\underline{\text { AA455157 }}$ & collagen, type $X V$, alpha I & 5'-CCA CCT ACC GAG CAT TCT TAT C-3' & \\
\hline & & & 5'-CAA TAC GTC TCG ACC ATC AAA G-3' & $197 \mathrm{bp}$ \\
\hline \multirow[t]{2}{*}{ IL2RA } & $\underline{\text { AA903183 }}$ & interleukin 2 receptor, alpha & 5'-CTG AGA GCA TCT GCA AAA TGA C-3' & \\
\hline & & & 5'-GGC CAC TGC TAC TTG GTA CTC T-3' & 242 bp \\
\hline \multirow[t]{2}{*}{ PDCD4 } & N71003 & programmed cell death 4 & 5'-CCG GTG ATG AAG AAA ATG CT-3' & \\
\hline & & & 5'-TGG TTG GCA CAG TTA ATC CA-3' & $207 \mathrm{bp}$ \\
\hline \multirow[t]{2}{*}{ ADORA2 } & N57553 & adenosine $\mathrm{A} 2 \mathrm{a}$ receptor & 5'-TCA ACA GCA ACC TGC AGA AC-3' & \\
\hline & & & 5'-ATG GCA ATG TAG CGG TCA AT-3' & 220 bp \\
\hline \multirow[t]{2}{*}{ RBM9 } & AA451903 & RNA binding motif protein 9 & 5'-AAC TCC TGA CTC AAT GGT TC-3' & \\
\hline & & & 5'-CAT TTT GTG TGC TGG GTG AG-3' & 194 bp \\
\hline \multirow[t]{2}{*}{ MAP2K7 } & $\underline{\mathrm{H} 85962}$ & mitogen-activated protein kinase kinase & 5'-ACC AGG CAG AAA TCA ACG AC-3' & \\
\hline & & & 5'-GAT GAA CGT CCC AAA GCA CT-3' & 224 bp \\
\hline \multirow[t]{2}{*}{ COL7AI } & $\underline{\text { AA598507 }}$ & collagen, tykpe VII, alpha I (epidermolysin) & 5'-AGC CCA GAT GTT TCC ACT CA-3' & \\
\hline & & & 5'-ACA AGA GGC AAT CCT TGG AGA-3' & $239 \mathrm{bp}$ \\
\hline
\end{tabular}

combining aliquots of RNA from 33 normal Rhesus tissues and was used on every slide as the array controller, to check overall sensitivity of array printing, and to monitor reverse transcription, labeling and hybridization efficiency. Sample hybridization was carried out at $55^{\circ} \mathrm{C}$ for sixteen hours. A laser detection system was used (GenePix 4000b, Axon Instruments, CA) to scan the finished slides. Intensity of the scanned images was digitalized through Genepix 4.0 software (Axon Inc., CA).

\section{Microarray analysis}

Data cleansing and statistical analysis was carried out using Genespring ${ }^{\circledR} 7.0$ (Agilent Tech., CA). Local background was subtracted from individual spot intensity. Genes that failed this 'background check' in any of the eight given experiments were eliminated from further analysis. Each chip was next subjected to intra-chip normalization (LOWESS). The genes that varied most between control and treated sample sets were selected via $t$-test analysis. The $p$-value cutoff was set at 0.05 . Four hundreds and thirty two genes were differentially expressed between SHIV -infected and control uninfected animals with $\mathrm{p}<0.05$.

The pattern of gene expression variability of the experimental set having reduced dimension was evaluated using principal component analysis (PCA) classifying SHIV positive and negative samples as the two variable classes [16].

\section{Real Time PCR}

The t-test result was corroborated through real time polymerized chain reaction (Real-time PCR). A webbased primer designing tool was used to design the primers for the selected genes [17]. The specificity of each primer sequence was further confirmed by running a blast search. Reverse transcription and Real-time PCR reactions were carried out using reverse transcription kit (Invitrogen, CA) and Real-time PCR kit (Roche, IN), respectively. Each reaction with five technical duplicates was run in ICycler machine (Bio-Rad, CA). Each sample was also amplified against the house-keeping probe of the experiment: glyceraldehyde 3 phosphate dehydrogenase (GAPDH). The resultant cycle threshold data from each real-time-PCR 'run' was converted to fold-change using an established algorithm [5].

Quantitative and qualitative verification of the PCR product was accomplished by performing $1 \%$ agarose gel electrophoresis using SYBR Green I (Kemtek, Rockville, MD). Gel images were captured using PharosFX Molecular Imager system (Bio-Rad, CA) scanner and analyzed using Quantity One software (Bio-Rad, CA).

\section{Authors' contributions}

EEC participated in the design of the study, carried out the microarray and real time PCR studies and participated in drafting the manuscript. $\mathrm{RH}$ participated in the design of 
Table 4: The list of some of the genes of interest.

\begin{tabular}{|c|c|c|c|}
\hline Gene ID & Symbol & Gene Name & Fold Change \\
\hline \multicolumn{4}{|c|}{ Cellular defense immunity: } \\
\hline AA424786 & GOLGA2 & golgi autoantigen, subfamily a2 & 2.802126 \\
\hline AA664195 & HLA-DRB3 (HLA-DRBI) & major histocompatibility complex, class II, DR beta I & 0.202677 \\
\hline $\mathrm{A} 1815229$ & LILRB3 & leukocyte immunoglobulin-like receptor, subfamily B, member 3 & 0.074432 \\
\hline$\overline{\mathrm{H} 96643}$ & FOSLI & FOS-like antigen-I & 0.284931 \\
\hline \multicolumn{4}{|c|}{ Cell growth/proliferation: } \\
\hline AA035384 & SDHD & succinate dehydrogenase complex & 0.287502 \\
\hline AA521228 & $\mathrm{HIBCH}$ & 3-hydroxyisobutyryl-Coenzyme A hydrolase & 4.260302 \\
\hline AA699573 & TCF2 & hepatic transcription factor 2 & 4.223543 \\
\hline $\mathrm{Al} 220577$ & TNP2 & transition protein 2 & 0.262051 \\
\hline$\overline{\mathrm{H} 06676}$ & ALDH5AI & aldehyde dehydrogenase 5 family & $2.38|24|$ \\
\hline Al798238 & P2RYII & peter pan homolog & 0.174406 \\
\hline \multicolumn{4}{|c|}{ Cell death/Apoptosis: } \\
\hline AA458838 & NOXA & phorbol-I 2-myristate-13-acetate-induced protein I & 3.872641 \\
\hline Al339248 & Bitl & CGI-I47 protein & 0.337378 \\
\hline$\overline{\mathrm{A} 1972925}$ & API5 & apoptosis inhibitor 5 & 0.17877 \\
\hline \multicolumn{4}{|c|}{ Molecular binding/Adhesion: } \\
\hline AA167269 & NAPILI & nucleosome assembly protein I-like I & 0.272199 \\
\hline AA424824 & DSTN & destrin & $2.876 \mid 46$ \\
\hline AA669637 & PNRCI & proline rich 2 & 0.142976 \\
\hline AA676840 & UTRN & utrophin & 2.340295 \\
\hline Al769340 & HRC & histidine-rich calcium-binding protein & 0.220777 \\
\hline$\underline{\mathrm{R} 16712}$ & ANLN & anillin & 0.280955 \\
\hline$\overline{\mathrm{T} 60070}$ & RAB40B & GTP-binding protein, member RAS oncogene family & 2.649082 \\
\hline AA426374 & TUBA2 & alpha tubulin 2 & 0.112352 \\
\hline$\overline{\mathrm{AA} 055163}$ & CASQ2 & calsequestrin 2 & 0.531223 \\
\hline AA521350 & Sep 15 & $15 \mathrm{kDa}$ selenoprotein & 0.33198 \\
\hline AA633747 & COL6A2 & collagen, type $\mathrm{VI}$, alpha 2 & 2.061697 \\
\hline AA634218 & PRAF2 & JM4 protein & 0.35942 \\
\hline AA922998 & PMS2L5 & postmeiotic segregation increased 2 -like 5 & 0.289763 \\
\hline$\overline{\mathrm{A} 1364103}$ & CINP & cyclin-dependent kinase 2 -interacting protein & 3.399017 \\
\hline$\overline{\mathrm{Al} 653424}$ & NUFIPI & nuclear fragile $\mathrm{X}$ mental retardation protein interacting protein I & 0.15423 \\
\hline W32272 & IQGAP2 & IQ motif containing GTPase activating protein & 3.137166 \\
\hline \multicolumn{4}{|c|}{ Signal Transduction: } \\
\hline AA42749I & TRAC & T-cell receptor active alpha-chain & 0.145492 \\
\hline $\mathrm{Al} 401275$ & CALCR & calcitonin receptor & 0.329203 \\
\hline$\underline{\mathrm{AA} 421819}$ & $\mathrm{CDH} 6$ & K-cadherin & 0.241252 \\
\hline \multicolumn{4}{|l|}{ Transport: } \\
\hline Al675394 & CLCA2 & calcium activated chloride channel & 3.802165 \\
\hline W9433I & CTNS & nephropathic cystinosis & 0.212335 \\
\hline$\underline{N 46828}$ & ITPKC & inositol I,4,5-trisphosphate 3-kinase C & 5.969257 \\
\hline \multicolumn{4}{|l|}{ Biogenesis: } \\
\hline AA056013 & MAGP2 & Microfibril-associated glycoprotein-2 & 2.312604 \\
\hline AA629189 & KRT4 & keratin 4 & 0.227523 \\
\hline$\underline{\mathrm{H} 27864}$ & & secretogranin II & 0.089345 \\
\hline
\end{tabular}

The first, second and third columns list the GeneBank ID, Symbol and Gene Name respectively. The Fourth column stands for the corresponding fold change of SHIV positive animal with respect to that of the control animal, averaged over the entire population, i.e. (Average fold change for all SHIV positive animals)/(Avg FC for all control animals) 


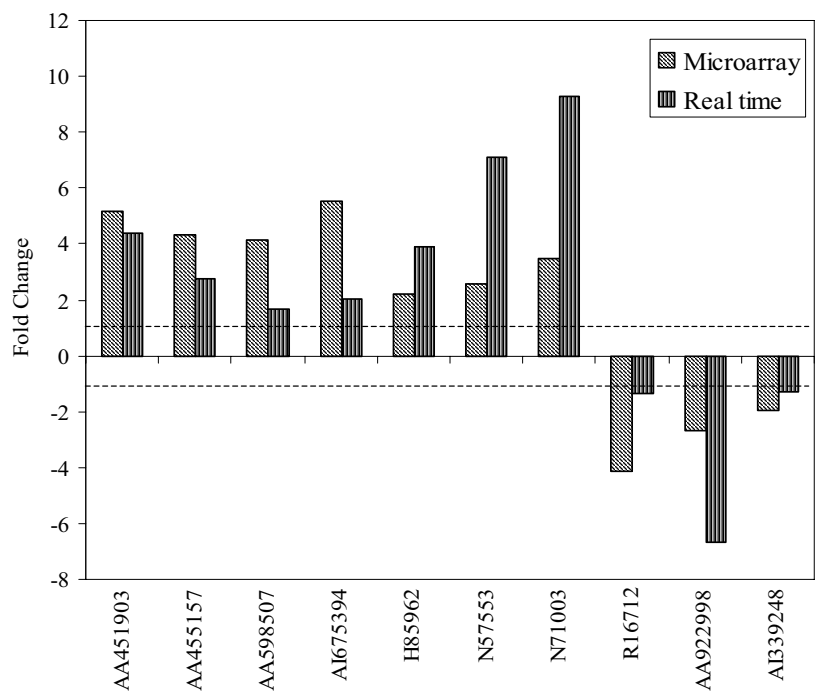

Figure 3

A comparative analysis of four selected genes using array analysis and Real-time PCR. RNA binding motif protein 9 (AA45 1903), collagen, type XV, alpha I (AA455I57), collagen, type VII, alpha I (AA598507), interleukin 2 receptor, alpha (AA903183), Chloride channel, calcium activated, family member 2 (Al675394), mitogen-activated protein kinase kinase (H85962), adenosine A2a receptor ( $\mathrm{N57553}$ ) and programmed cell death 4 ( $\mathrm{N71003})$ were up regulated in SHIV infected animals while postmeiotic segregation increased 2like (AA922998), Bcl-2 inhibitor of transcription (Al339248) and Anillin ( $\mathrm{R} / 67 / 2)$ were down regulated.

the study, carried out the microarray data analysis, data mining and participated in drafting the manuscript. NC participated in the microarray data analysis and participated in drafting the manuscript. AP participated in the microarray and real time PCR studies.

SAM participated in the microarray and real time PCR studies. MJ conceived of the study, and participated in its design and coordination. All authors read and approved the final manuscript.

\section{Acknowledgements}

EEC wants to extend thanks to LTC Gary D. Coleman and LTC Keith E. Steele for giving her the time to devote to this project in the face of other equally pressing mission requirements.

\section{References}

I. Nath BM, Schumann KE, Boyer JD: The chimpanzee and other non-human-primate models in HIV-I vaccine research. Trends Microbiol 2000, 8(9):426-3I.

2. Murray EA, Rausch DM, Lendvay J, Sharer LR, Eiden LE: Cognitive and motor impairments associated with SIV infection in rhesus monkeys. Science 1992, 255(5049): 1246-9.

3. Blackburn R, Clerici M, Mann D, Lucey DR, Goedert J, Golding B, Shearer GM, Golding H: Common sequence in HIV I GP4I and HLA class II beta chains can generate crossreactive autoantibodies with immunosuppressive potential early in the course of HIV I infection. Adv Exp Med Biol 199I, 303:63-9.
4. Lane BR, Markovitz DM, Woodford NL, Rochford R, Strieter RM, Coffey MJ: TNF-alpha inhibits HIV-I replication in peripheral blood monocytes and alveolar macrophages by inducing the production of RANTES and decreasing C-C chemokine receptor 5 (CCR5) expression. J Immunol I999, I 63(7):3653-6I.

5. Hammamieh R, Chakraborty N, Das R, Jett M: Molecular impacts of antisense complementary to the liver fatty acid binding protein (FABP) mRNA in DU 145 prostate cancer cells in vitro. J Exp Ther Oncol 2004, 4(3): 195-202.

6. Hammamieh R, Chakraborty N, Laing M, Liu Z, Mulligan J, Wang Y, Jett $M$ : GeneCite: tool for high throughput literature and pathway mining. in press.

7. Wang C, Tang J, Song W, Lobashevsky E, Wilson CM, Kaslow RA: HLA and cytokine gene polymorphisms are independently associated with responses to hepatitis B vaccination. Hepatology 2004, 39(4):978-88.

8. Leal DB, Streher CA, Bertoncheli Cde M, Carli LF, Leal CA, da Silva JE, Morsch VM, Schetinger MR: HIV infection is associated with increased NTPDase activity that correlates with CD39-positive lymphocytes. Biochim Biophys Acta 2005, I746(2):129-34.

9. Koutsilieri E, Sopper S, Heinemann T, Scheller C, Lan J, Stahl-Hennig C, ter Meulen V, Riederer P, Gerlach M: Involvement of microglia in cerebrospinal fluid glutamate increase in SIV-infected rhesus monkeys (Macaca mulatta). AIDS Res Hum Retroviruses 1999, I5(5):47I-7.

10. Flo RW, Naess A, Nilsen A, Harthug S, Solberg CO: A longitudinal study of phagocyte function in HIV-infected patients. Aids 1994, 8(6):77|-7.

II. Jolly C, Kashefi K, Hollinshead M, Sattentau QJ: HIV-I cell to cell transfer across an Env-induced, actin-dependent synapse. J Exp Med 2004, 1 99(2):283-93.

12. Torrealba J: Selenium binding protein I: passive or active role in disease? Am J Transplant 2005, 5( ( 0):2593.

13. Shoeman RL, Kesselmier C, Mothes E, Honer B, Traub P: Non-viral cellular substrates for human immunodeficiency virus type I protease. FEBS Lett I991, 278(2):199-203.

14. Matsubara M, Jing T, Kawamura K, Shimojo N, Titani K, Hashimoto K, Hayashi N: Myristoyl moiety of HIV Nef is involved in regulation of the interaction with calmodulin in vivo. Protein Sci 2005 , I4(2):494-503.

15. Liu QH, Williams DA, McManus C, Baribaud F, Doms RW, Schols D, De Clercq E, Kotlikoff MI, Collman RG, Freedman BD: HIV-I gp I 20 and chemokines activate ion channels in primary macrophages through CCR5 and CXCR4 stimulation. Proc Natl Acad Sci USA 2000, 97(9):4832-7.

16. Raw data [http://www.ncbi.nlm.nih.gov/geo/]. Platform number: GPL3395

17. PCR design [http://frodo.wi.mit.edu/cgi-bin/primer3]

\section{Publish with Biomed Central and every scientist can read your work free of charge}

"BioMed Central will be the most significant development for disseminating the results of biomedical research in our lifetime. "

Sir Paul Nurse, Cancer Research UK

Your research papers will be:

- available free of charge to the entire biomedical community

- peer reviewed and published immediately upon acceptance

- cited in PubMed and archived on PubMed Central

- yours - you keep the copyright

Submit your manuscript here:

http://www.biomedcentral.com/info/publishing_adv.asp
Biomedcentral 